\title{
The Fullfillment of The Social Rights for Child Client With Parole Status at Correctional Center in South Jakarta-Indonesia
}

\author{
Sarinah $^{1}$, Fentiny Nugroho $^{2}$, Desi Setiana ${ }^{3}$ \\ \{sarinahdrs@gmail.com ${ }^{1}$, fentiny2015@gmail.com ${ }^{2}$, desi.setiana@gmail.com ${ }^{3}$ \} \\ ${ }^{1}$ Undergraduate Program in Social Welfare, Faculty of Social and Political Sciences, Universitas \\ Indonesia , Indonesia \\ ${ }^{2}$ Lecture of Social Welfare Departement, Universitas Indonesia, Indonesia \\ ${ }^{3}$ Corectional Center of South Jakarta. Ministry of Law and Human Rights, Indonesia
}

\begin{abstract}
This study discusses the fulfillment of social rights for clients with parole status, that reveal and resolves the fulfillment of children's rights obtained with second-generation human rights which is hardly found in other research. This study uses a qualitative approach with a descriptive design is applied through data gathering techniques include literature and documentary search, in-depth interviews and observations. The results show that as long as the child underwent a period of conviction outside the institution experienced an obstacle, namely the threat from the family of the victim who wanted to take revenge so that it affected the fulfillment of the social rights of child clients, especially the rights to be treated with dignity. The existence of discriminatory actions on child clients such as ridicule, labeling as a juvenile delinquency and exclusion make the child's clients tend to withdraw from society and have low self-confidence. Moreover violation occurs and how relation human rights with the law are observed. Finally, this research found and suggested that all parties family and the government represented by the Community Counselor of Correctional Center are required to handle this situation in order to fulfill the children's rights.
\end{abstract}

Keywords: Clients with parole status, the fulfillment of social rights, law.

\section{Introduction}

According to Asshiddiqie [1] human rights are rights inherent in human beings based on human nature from birth, may not be deprived or revoked and is not a gift from an organization or another part. In the legal context of the Republic of Indonesia, the state is the parties responsible for the protection, promotion, enforcement, and fulfillment of human rights [2]. Based on its development there are three generations of human rights as stated by Ife [3] human rights of the first generation are also referred to as civil and political rights, second generation are economic, social, cultural rights, and the third generation refers to collective rights.

Human rights of second-generation are referred to as positive rights because they imply a much more active and positive role for the state. Rather than simply protecting rights, the state is required to take a stronger role in actually ensuring that these rights are realised through various forms of social provision [3]. The state also regulates and gives full attention to the efforts of the problem solving process and the fulfillment rights of Child in Conflict with The Law as evidenced by the Law Republic of Indonesia No.11/2012 concerning the Juvenile Justice System [4]. 
The problem solving of children who are dealing with the law is through the Law Republic of Indonesia No.11/2012 concerning the Juvenile Justice System Article 5 namely the settlement of criminal cases involving the perpetrators, victims, families of perpetrators / victims, and other parties related parties to jointly seek a fair solution by emphasizing recovery back to its original state, and not retaliation [4]. Based on these legal regulations, it can be seen that the rights of children who undergo legal proceedings should not be ignored such as the right not to be arrested and not detained or imprisoned except as a last resort and in the shortest period of time [5].

In Article 4 Paragraph 1D the Law Republic of Indonesia No.11/2012 concerning the Juvenile Justice System discusses one of rights is got parole [4]. Parole is a coaching program to integrate prisoners and children into people's lives after agreeing to the conditions determined during the monitoring of external punishment [6], besides, children are at risk of getting violent actions and the existence of stigmatization in the community [7]. This requirement is strongly opposed to the fulfillment of children's social rights especially the rights to be treated with dignity which is included in the second generation of human rights.

The reason for choosing the Correctional Center of South Jakarta-Indonesia as the research location because of the phenomenon Child in Conflict with the Law in Indonesia, especially in the DKI Jakarta tends to increase every year. However, the Correctional Center of South Jakarta-Indonesia as implementation unit that has a role to social research as references for court processing.

Data gathering techniques include a literature search [8]. Documentary search, in-depth interviews, and observations. The data analysis technique uses open coding, axial, and selective coding and techniques to improve the quality of research using triangulation from the point of view of various informants and triangulation theory [9].

Thus, this study would like to describe about fulfillment of social rights obtained by clients with parole status at the Correctional Center of South Jakarta-Indonesia. This study uses a qualitative approach with a descriptive design. General qualitative research tends to be more open to using a wide range of evidence and discovering new issues [9]. The informants in this study consisted of six people with details of three clients with parole status and three Community Counselors of Correctional Centers of South Jakarta-Indonesia.

\section{Results And Discussion}

\subsection{Clients Profile and Their Treatments}

This study found that, the clients have a special treatment on their cases, provided by correctional center. Here, the results showed that three clients of parole status in Correctional Center in of South Jakarta-Indonesia have an optimal guidance program, its implemented when child clients are directly integrated in the community, their get discriminatory actions of ridicule, exclusion and the threat of family revenge victims thus hamper the fulfillment of social rights, namely the right to be treated with dignity which is included in second generation of human rights.

Children in conflict with the law, especially for clients who have parole status is to seek child clients to undergo punishment with short insurance and to consider all the needs of child clients as an effort to fulfill human rights. In its implementation, the government gives parole to children so that children can easily interact with their surrounding environment. Then, to avoid the occurrence of criminal acts committed by child clients, the government is represented by the Community Counselor of Correctional Center. 
Based on direct interview, three child clients were guided by each Community Counselor of Correctional Center. The implementation of this guidance take once a month, and they come directly to the Correctional Center or home visits by the officers, to monitors what a poisitif improvements by clients and their family as well. Guidance given by the Community Counselor of Correctional Center to child clients is based on the principle of guidance that does not discriminate between child clients, namely the Community Counselor of Correctional Center provides guidance with the same quality on the child's client and does not view the background of the child's client either child clients who come from rich families or not. This shows that the Community Counselor of Correctional Center has carried out its role in accordance with Article 2C the Law Republic of Indonesia No.11 / 2012 concerning the Juvenile Justice System, refers to the principle of non-discrimination [4].

\subsection{Monitoring and Guidance: An Officer Approached}

Guidance of the Community Counselor of Correctional Center with quite diverse such as personality guidance consisting of guidance on religion, social relations with the family and the surrounding environment and the development of the school. Personality guidance in the form of religious material discusses recommendations for performing prayer services five times, this material shows good benefits for child clients such as children who are diligent in worshiping. This is in accordance with the theory put forward by Karim [10] that one of the goals of guidance is to improve personality client, which makes the child's client obey and religious orders.

Material about the social relations of child clients with family and community shows the creation of closer relationships between child and family clients and the provision of more loving care and attention to child clients. This is in accordance with what was stated by Karim [10] that correctional guidance provided by the Community Counselor of Correctional Center has an effect on improving the social relations of child and family clients, with this guidance will create a more harmonious family condition, children obey family rules and parents become role models for children. In addition, based on the results of observations and interviews, it shows that the social relations of the child's clients with the surrounding environment are still not optimal because of discriminatory actions in the form of ridicule, exclusion and the threat of revenge from the victim's family.

\subsection{The Clients Improvements through Reconciliation}

The existence of discrimination makes child clients have low self-confidence and do not want to interact with the surrounding environment. This condition is related to what is stated by Direktorat Jenderal Pemasyarakatan Kementerian Hukum dan HAM Republik Indonesia [7] namely children at risk of getting violent actions and the existence of stigmatization in the community, and this condition shows the second generation of human rights violations in accordance with Ife theory [3] that one example of the rights that must be fulfilled is the right to be treated with dignity and the government must play an active role in fulfilling this right. The statement from Ife [3] is supported by Mulyana [2] that the state is the most vital and responsible party in fulfilling the rights stated in second generation human rights, besides that it must provide protection and endeavor in fulfilling human rights. In the process of correctional guidance, the role of the state is represented by a Community Counselor of Correctional Center. For this reason, the Community Counselor of Correctional Center is expected to be able to provide protection to child clients so that the rights to be treated with dignity is protected. 
Although the client's child is still undergoing a period of punishment, the child's social rights in the form of education are still fulfilled. Based on the findings of the field it was found that two child clients were undergoing ninth grade education in junior high school and another 11 th grade child client in high school. Then, the material of children's client social relationships with their families and surrounding communities is in the form of the Community Counselor of Correctional Center's efforts to monitor and encourage child clients to interact and lead good relationships by managing all existing regulations. Refers to the findings of the field, the development of schools from three child clients is running optimally plus the material provided by the Community Counselor of Correctional Center regarding the development of the school of child clients. Guidance provides optimal benefits for child clients.

Based on the results of the field findings and discussion, this study recommends families who are the closest parties to child clients to always give more intensive attention to child clients and pay attention to the needs of children's rights, especially children's social rights. The existence of discriminatory actions obtained by child clients, the family must be a protector and provide security for the child's clients. Then, the next recommendation is that the government is represented by the Community Counselor of Correctional Center to be required to handle the issue of fulfilling children's social rights. the Community Counselor of Correctional Center is expected to be an advocate and mediator who provides alternative solutions to problems and becomes a mediator between child clients and the families of victims so there is no violation of rights, especially the social rights of children.

\section{Acknowledgements}

This could not have been accomplished without the assistance of many people whose contributions are gratefully acknowledged,We would like to thanks the Directorate of Research and Community Service of Universitas Indonesia for supporting this research, the Correctional Center of South Jakarta the Ministry of Law and Human Rights Republic of Indonesia for giving us the opportunity to conduct research. In addition, we also thanks the informants is child clients of parole status and community mentors who have been willing to take the time to provide information related to the research that we do.

\section{References}

[1] A. Jimly, Pokok-Pokok Hukum Tata Negara Indonesia Pasca Reformasi. Jakarta: PT. Buana Indah Populer, 2007.

[2] A. Mulyana, "HAM dan Pemerintah Daerah: Ikhtiar Membumikan HAM di Level Lokal," J. HAM Komisi Nas. Hak Asasi Mns., vol. XIII, no. XIII, pp. 147-184, 2016.

[3] J. Ife, Human Rights and Social Work. Towards Rights-Based Practice. Cambridge: Cambridge University Press, 2008.

[4] Undang-Undang Nomor 11 Tahun 2012 tentang Sistem Peradilan Pidana Anak. .

[5] Kementerian Pemberdayaan Perempuan dan Perlindungan Anak (KPPPA) RI, Profil Anak Indonesia 2018. Jakarta: Kementerian Pemberdayaan Perempuan dan Perlindungan Anak (KPPPA) Republik Indonesia, 2018.

[6] Peraturan Menteri Hukum dan Hak Asasi Manusia Republik Indonesia Nomor 03 Tahun 2018 tentang Syarat dan Tata Cara Pemberian Remisi, Asimilasi, Cuti Mengunjungi Keluarga, Pembebasan Bersyarat, Cuti Menjelang Bebas, dan Cuti Bersyarat. .

[7] Direktorat Bimbingan Kemasyarakatan dan Pengentasan Anak, Modul Penyuluhan 
Penanganan Anak yang Berhadapan dengan Hukum (ABH) terkait Diversi dan Keadilan Retoratif bagi Petugas Pemasyarakatan. Jakarta: Direktorat Jenderal Pemasyarakatan Kementerian Hukum dan HAM Republik Indonesia, 2013.

[8] E. Babbie, The practice of social research 12th edition. Wadsworth: Cengage Learning, 2010.

[9] W. L. Neumann, Social Research Method: Qualitative and Quantitative Approach. Fifth Edition. Boston: Allyn and Bacon, 2003.

[10] S. A. Karim, Bimbingan dan Penyuluhan Warga Binaan Pemasyarakatan. Jakarta: Badan Pembinaan Sumber Daya Manusia, Departemen Hukum dan HAM RI, 2007. 